\title{
TheRole of Emotional Intelligence and Tolerance of Ambiguity in Predicting EFL Learners' Language Learning Strategies
}

\author{
Mania Nosratinia ${ }^{1}$, Maryam Niknam $^{2}$, Elnaz Sarabchian $^{3}$ \\ ${ }^{I}$ Assistant Professor, Islamic Azad University at Central Tehran, English Department, Tehran, Iran. \\ ${ }^{2}$ MA Candidate, Islamic Azad University at Central Tehran, English Department, Tehran, Iran. \\ ${ }^{3}$ MA in TEFL, Islamic Azad University at Central Tehran, English Department, Tehran, Iran.
}

\begin{abstract}
The aim of this study was to investigate the power of emotional intelligence (EI) and ambiguity tolerance in predicting EFL learners' language learning strategy (LLS)and probe any possible relationship among these variables. The participants of the study were 130 EFL students, between 18 -30 years old, majoring in English Translation and English Literature at Islamic Azad University at Central Tehran, Iran. The instruments utilized in this study were a) Strategy Inventory for Language Learning (SILL) to assess the learners' strategy-use-frequency in language learning, b) Bar-On Emotional Quotient Inventory (EQ-I) to measure learners' emotional intelligence, and c) Second Language Tolerance of Ambiguity Scale (SLTAS) to identify participants' tolerance of ambiguity. The results of the study showed that regression model including EI predicted about 6.8 percent, and tolerance of ambiguity 3.2 percent of students' LLSs. Also, running Pearson correlation indicated a statistically significant relationship between learners' EI and LLSs and the components of both EI and SILL. In addition, Pearson correlation revealed statistically significant relationship between learners' tolerance of ambiguity and their overall LLSs use, and components of SILL.
\end{abstract}

Key words:language learning strategies, emotional intelligence, tolerance of ambiguity, EFL learners, effective learning

\section{Introduction}

In the area of teaching and learning a second/foreign language, there has been an increasing interest in changing the focus from the product of language learning to the processes through which learning takes place [1].As a result of this change in emphasis, language-learning strategies (LLSs) have emerged not only as integral components of various theoretical models of language proficiency $[2,3,4,5]$ but also as a means of achieving learner autonomy in the process of language learning [6,7].Raising students' awareness regarding their LLSs might make them not only more prepared for learning but also more analytic about the strategies they make use of [8]. Research in this area has shown that not all learners use LLSs in the same fashion. Use of LLSs is influenced by number of factors [7], and the frequency and variety of LLSs vary among different individuals and depend on a number of variables [9]. In studies conducted by Cohen [10], Ehrman and Oxford [11], MacIntyre and Gardner [12], and Reid [13], these individual differences have been identified as motivation, gender, learning style, previous experience, and different personality types.

Toincrease progress in learners' LLSs, the individual differences must be recognized and attended to. The aim of this study is to find the relationship and pattern oftwo different psychological factors, emotional intelligence (EI) and tolerance of ambiguity that might affect EFL learners' use of language strategies.

\subsection{Learning Strategies}

As Wenden [14] reminds us, an old proverb states, "give a man a fish and he eats for a day; teach him how to fish and he eats for a life time". Interpretation of this proverb in the language learning and teaching might be that if students are provided with answers, the immediate problem is solved. However, if they are taught the strategies to work out the answers for themselves, they are empowered to manage their own learning.

Ellis [15] states, "The actions that learners perform in order to learn a language have been variously labeled behaviors, tactics, techniques, and strategies". The term learning strategies can bedefined as "specific actions taken by the learner to make learning easier, faster, more enjoyable, more self directed, more effective, and more transferable to new situations" [7].

As Chamot, Barnhardt, El-Dinnary, and Rubbins[16] point out "Differences between more effective learners and less effective learners were found in the number and range of strategies used".Researchers $[7,17,18]$ support the belief that learners who receive learner training, generally learn better than those who do not. In addition, there is a relationship between the frequent use of learning strategies and achievement in the language $[19,20,21]$. 


\subsection{Emotional Intelligence}

Over the last decade, the concept of EI, as a factor for differentiating students' life success, has received attention in popular literature [22].However, as early as 1920, Thorndike [23] hypothesized that true intelligence was composed of not only academic elements, but involved emotional and social elements. Thorndike [24] defined social intelligence as the ability to act wisely in human relations. Salovey and Mayer [25] define EI as "the ability to monitor one's own and others' feelings and emotions, to discriminate among them and to use this information to guide one's thinking and actions". Goleman [26] stated that "abilities such as being able to motivate oneself and persist in the face of frustrations, to control impulses and delay gratification, to regulate one's moods and keep distress from swamping the ability to think, to emphasize and to hope."Bar-On's [27] cited EI as "an array of noncognitive capabilities, competencies, and skills that influence one's ability to succeed in coping with environmental demands and pressures."

EI has been reported to count as the overriding factor contributing to success in a number of varied arenas including work settings [28], classroom performance [29], cognitive tasks [30], and Contextual performance [28]. EI is also said to be a crucial factor in organization change [31, 32], leadership $(33,34,35,36]$, management performance[37], teachers' burnout level [38], university professors' self- efficacy [39] and life satisfaction [40].

\subsection{Tolerance of Ambiguity}

Tolerance of Ambiguity, also referred to as language ego, ego boundaries, or cognitive flexibility [41, 42], refers to how an individual or group "perceives and processes information about ambiguous situations or stimuli when confronted by an array of unfamiliar, complex, or incongruent clues" [43].

Because the concept of tolerance of ambiguity is applied to different aspects of language learning, individual definitions of the concept have varied in focus. In the context of reactions to specific language classroom events, Ely [44] defined tolerance of ambiguity as one's acceptance of confusing situations and a lack of clear lines of demarcation. Naiman, Frohlich, Stern, \&Todesco[45] and Ehrman\& Oxford [11] more broadly referred to the concept as a facet of personality characteristics. Ehrman and Oxford [46] specifically linked it to risk taking because those who can tolerate ambiguity are more likely to take risks in language learning, an essential factor for making progress in the language [44, 47,48,49]. Ehrman[41] provided a three part model of the concept which includes "the ability to take in new information ... to hold contradictory or incomplete information without either rejecting one of the contradictory elements or coming to premature closure on an incomplete schema ... [and] to adapt one's existing cognitive, affective, and social schemata in light of new material."

Ellis [50] provided a description, which may also have implications for the effect caused by the use of the learner's first language in second language studies. Ellis described tolerance of ambiguity as a dimension of second language learning, which "entails an ability to deal with ambiguous new stimuli without frustration and without appeals to authority [e.g., the first language]. It allows for indeterminate rather than rigid categorization".

The specific trait of ambiguity tolerance can be assumed as the reflections of people personality and would affect many aspects of people's life, learning and proficiency of learners [44]. Thus, tolerance of ambiguity is commonly known to play a decisive role in various aspects of language performance and learners' beliefs about learning (e.g. reading comprehension and translation) [51,52].

Various studies have shown that learners who can tolerate moderate levels of ambiguity are more likely to persist in language learning $[45,53]$ and to achieve more than those who cannot tolerate ambiguity $[41,54,55]$.

In this regard, the purpose of this study is to identify interrelated patterns of EI, tolerance of ambiguity, and LLSs. In line with the above purpose, two research questions are posed:

1) Is there any significant relationship among EFL learners' EI, tolerance of ambiguity, and LLSs?

2) Is there any significant difference in the predictability of EFL learners'LLSs through their EI, and tolerance of ambiguity?

\subsection{Participants}

\section{Materials and Methods}

One hundred and thirty students majoring in English Translation and English Literature at Islamic Azad University, CentralTehran, Iran between 18 -30 were non-randomly selected and given three questionnaires. Among these one hundred and thirty participants, 30 of them were males (39\%) and 100 of them were females (61\%).During the study process, 12 students were excluded from data analysis due to missing questionnaire responses, or disagreement to answer certain questionnaire.

\subsection{Instruments}

2.2.1Strategy Inventory for Language Learning (SILL):SILLquestionnaire, ESL/EFL version 7.0, contains 
50 items organized according to the six-subset taxonomy (memory, cognitive, compensation, metacognitive, affective, and social strategies). The instrument measures the type and the frequency of strategy use through 50 statements. Items 1-9 concern the effectiveness of memory (memory strategies); items 10-23 concern the use of mental processes (cognitive strategies); items 24-29 are the compensation for missing knowledge (compensation strategies); items 30-38 deal with the organization and evaluation of learning (metacognitive strategies); items 39-44 concern emotion management (affective strategies); and items 45-50 deal with learning with others (social strategies). Students answered each item statement using a 5-point Likert-scale that ranged from one (never true of me) to five (always or almost true of me). According to Ehrman and Oxford [11], SILL has consistently scored above 0.90 using Cronbach's alpha, which indicates high internal reliability. Oxford (56) reported Cronbach's alpha of 0.96 for SILL.

2.2.2Bar-On Emotional Quotient Inventory (EQ-I):Bar-On EQ-I test, designed by Bar-On in 1980, is a selfreport measure of emotionally and socially intelligent behavior and provides an estimateof emotional-social intelligence. The test includes 90 items in the form of short sentences and employs a five-point response scale with a textual response format ranging from "very seldom" or "not true of me" to "very often" or "true of me". Each item has the value of 5 ranging to 1 . EI test is suitable for individuals 17 years of age and older and takes approximately 30 minutes to complete. The K-R21 reliability of this test in the present study was 0.93 .

2.2.3Second Language Tolerance of Ambiguity Scale (SLTAS):To identify the degree of participants' tolerance of ambiguity, the Second Language Tolerance of Ambiguity Scale (SLTAS), developed by Ely [57] was used in this study.The test includes 12 items and employs 4-point response scale ranging from "strongly agree" or"agree" to"disagree" or"strongly disagree". This test takes approximately five minutes to complete and students' score can range from 12 to 48 . The reported internal consistency reliability of SLATS is 0.84 and the $\mathrm{K}-\mathrm{R} 21$ reliability of SLTAS is 0.63 in this study.

\section{Procedure}

A brief introductory session with students studying at Islamic Azad University was arranged. Students were informed that their performance on the test is voluntary and will not affect their final course results and they were assured for the confidentiality of the data gathering procedure. After giving an oral instruction of how to perform on the questionnaires each participant received a package of research instruments containing the BarOn EQ-I, SLTAS, and SILLquestionnaires along with the written instructions for each form. The students were asked to fill the questionnaires and return the results on the same or next session.

\section{Results}

\subsection{Correlation between EI and Tolerance of Ambiguity}

The results of the Pearson correlation $(\mathrm{R}(128)=.136, \mathrm{P}=.122>.05)$ indicated a statistically non-significant relationship between the two variables. Thus, as displayed in Table 4.1, it can be concluded that there is no statistically significant relationship between EFL learners' EI and their tolerance of ambiguity.

Table 4.1: Correlation between Emotional Intelligence and Tolerance of Ambiguity

\begin{tabular}{|l|l|l|}
\hline \multicolumn{2}{|c|}{} & $\begin{array}{l}\text { Emotional } \\
\text { Intelligence }\end{array}$ \\
\hline \multirow{3}{*}{ Tolerance of Ambiguity } & Pearson Correlation & $\mathbf{. 1 3 6}$ \\
\cline { 2 - 3 } & Sig. (2-tailed) & .122 \\
\cline { 2 - 3 } & $\mathrm{N}$ & $\mathbf{1 3 0}$ \\
\hline
\end{tabular}

\subsection{Correlation between EI and LLSs}

The results of the Pearson correlation $(\mathrm{r}(128)=.761, \mathrm{P}=.003<.05)$ indicated a statistically significant relationship between the EI and LLSs. Thus as illustrated in Table 4.2, it can be concluded that there is statistically significant relationship between EFL learners' EI and their use of LLSs.

Table 4.2: Correlation between EI and LLSs

\begin{tabular}{|l|l|l|}
\hline \multicolumn{2}{|l|}{} & $\begin{array}{l}\text { Language } \\
\text { Learning } \\
\text { Strategies }\end{array}$ \\
\hline \multirow{3}{*}{ Emotional Intelligence } & Pearson Correlation & .761 \\
\cline { 2 - 3 } & Sig. (2-tailed) & .003 \\
\cline { 2 - 3 } & $\mathbf{N}$ & 130 \\
\hline$* *$ Correlation is significant at the 0.01 level (2-tailed). \\
\hline
\end{tabular}

However, for further analysis, correlations between different categories of SILL and EI were calculated using Pearson Correlation. (Table 4.3) 
Table 4.3: Correlation Coefficient of Participants' EI and SILL

\begin{tabular}{|c|c|c|c|c|c|c|c|}
\hline & & Affective & Metacognitive & Compensation & Cognitive & Memory & $\begin{array}{l}\text { Socia } \\
1\end{array}$ \\
\hline \multirow{2}{*}{$\begin{array}{l}\text { Problem } \\
\text { solving }\end{array}$} & PearsonCorrelation & .564 & .776 & .687 & .777 & .766 & .543 \\
\hline & Sig. (2-Tailed) & .037 & .045 & .039 & .064 & .051 & .002 \\
\hline \multirow[t]{2}{*}{ Happiness } & PearsonCorrelation & .601 & .789 & .611 & .716 & .702 & .540 \\
\hline & Sig. (2-Tailed) & .044 & .013 & .056 & .042 & .023 & .011 \\
\hline \multirow[t]{2}{*}{ Independence } & PearsonCorrelation & .614 & .745 & .657 & .799 & .641 & .569 \\
\hline & Sig. (2-Tailed) & .018 & .054 & .040 & .078 & .056 & .049 \\
\hline \multirow{2}{*}{$\begin{array}{l}\text { Stress } \\
\text { Tolerance }\end{array}$} & PearsonCorrelation & .701 & .711 & .666 & .711 & .639 & .578 \\
\hline & Sig. (2-Tailed) & .011 & .057 & .033 & .021 & .078 & .065 \\
\hline \multirow{2}{*}{$\begin{array}{l}\text { Self } \\
\text { Actualization }\end{array}$} & PearsonCorrelation & .655 & .699 & .699 & .721 & .639 & .590 \\
\hline & Sig. (2-Tailed) & .015 & .057 & .066 & .032 & .057 & .039 \\
\hline \multirow{2}{*}{$\begin{array}{l}\text { Emotional } \\
\text { Self } \\
\text { Awareness }\end{array}$} & PearsonCorrelation & .609 & .789 & .685 & .742 & .611 & .523 \\
\hline & Sig. (2-Tailed) & .006 & .045 & .038 & .028 & .059 & .022 \\
\hline \multirow{2}{*}{$\begin{array}{l}\text { Reality } \\
\text { Testing }\end{array}$} & PearsonCorrelation & .544 & .700 & .677 & .788 & .600 & .549 \\
\hline & Sig. (2-Tailed) & .034 & .061 & .026 & .054 & .021 & .031 \\
\hline \multirow{2}{*}{$\begin{array}{l}\text { Interpersonal } \\
\text { Relationship }\end{array}$} & PearsonCorrelation & .678 & .614 & .632 & .723 & .703 & .541 \\
\hline & Sig. (2-Tailed) & .067 & .009 & .041 & .006 & .001 & .088 \\
\hline \multirow[t]{2}{*}{ Optimism } & PearsonCorrelation & .699 & .784 & .701 & .791 & .642 & .555 \\
\hline & Sig. (2-Tailed) & .071 & .061 & .045 & .088 & .057 & .064 \\
\hline \multirow[t]{2}{*}{ Self Regard } & PearsonCorrelation & .560 & .740 & .699 & .777 & .641 & .533 \\
\hline & Sig. (2-Tailed) & .091 & .041 & .057 & .063 & .087 & .023 \\
\hline \multirow{2}{*}{$\begin{array}{l}\text { Impulse } \\
\text { Control }\end{array}$} & PearsonCorrelation & .669 & .796 & .682 & .766 & .699 & .511 \\
\hline & Sig. (2-Tailed) & .045 & .012 & .054 & .067 & .066 & .045 \\
\hline \multirow[t]{2}{*}{ Flexibility } & PearsonCorrelation & .689 & .743 & .699 & .798 & .671 & .566 \\
\hline & Sig. (2-Tailed) & .024 & .021 & .056 & .022 & .034 & .052 \\
\hline \multirow{2}{*}{$\begin{array}{l}\text { Social } \\
\text { Responsibility }\end{array}$} & PearsonCorrelation & .674 & .712 & .698 & .642 & .630 & .645 \\
\hline & Sig. (2-Tailed) & .022 & .046 & .021 & .067 & .034 & .022 \\
\hline \multirow[t]{2}{*}{ Empathy } & PearsonCorrelation & .504 & .698 & .642 & .700 & .691 & .601 \\
\hline & Sig. (2-Tailed) & .101 & .022 & .067 & .034 & .055 & .011 \\
\hline \multirow[t]{2}{*}{ Assertiveness } & PearsonCorrelation & .652 & .714 & .655 & .765 & .611 & .540 \\
\hline & Sig. (2-Tailed) & .011 & .021 & .053 & .056 & .068 & .037 \\
\hline
\end{tabular}
of SILL.

As shown in Table 4.3, there are significant correlations among the components of EI and the components

\subsection{Correlation between Tolerance of Ambiguity and Overall Use of LLSs}

As Table 4.4 shows the results of the Pearson correlation $(\mathrm{r}(128)=.711, \mathrm{P}=.016<.05)$ indicate a statistically significant relationship between the two variables. Thus, as Table 4.4 illustrates, there is statistically significant relationship between EFL learners' tolerance of ambiguity and their use of LLSs.

Table 4.4: Correlation between Tolerance of Ambiguity and Overall Use of LLSs

\begin{tabular}{|l|l|l|}
\hline \multicolumn{2}{|l|}{} & $\begin{array}{l}\text { Language } \\
\text { Learning } \\
\text { Strategies }\end{array}$ \\
\hline \multirow{3}{*}{ Tolerance of Ambiguity } & Pearson Correlation & $.711^{*}$ \\
\cline { 2 - 3 } & Sig. (2-tailed) & .016 \\
\cline { 2 - 2 } & $\mathrm{N}$ & 130 \\
\hline *. Correlation is significant at the 0.05 level (2-tailed). \\
\hline
\end{tabular}

For further analysis, correlations between different categories of SILL and Tolerance of Ambiguity were calculated through Pearson Product Correlation. (Table 4.5) 
The Role of Emotional Intelligence and Tolerance of Ambiguity in Predicting EFL Learners'

Table 4.5: Correlation Coefficient of Participants' SILL and Tolerance of Ambiguity

\begin{tabular}{|c|c|c|}
\hline \multicolumn{3}{|l|}{ Correlations } \\
\hline & & T of $A$ \\
\hline \multirow{3}{*}{ Metacognitive } & Pearson Correlation & $.795^{* *}$ \\
\hline & Sig. (2-tailed) & .005 \\
\hline & $\mathbf{N}$ & 130 \\
\hline \multirow{3}{*}{ Cognitive } & Pearson Correlation & $.701^{* *}$ \\
\hline & Sig. (2-tailed) & .002 \\
\hline & $\mathbf{N}$ & 130 \\
\hline \multirow{3}{*}{ Memory } & Pearson Correlation & $.628^{* * *}$ \\
\hline & Sig. (2-tailed) & .008 \\
\hline & $\mathbf{N}$ & 130 \\
\hline \multirow{3}{*}{ Compensation } & Pearson Correlation & $.601^{* *}$ \\
\hline & Sig. (2-tailed) & .001 \\
\hline & $\mathbf{N}$ & 130 \\
\hline \multirow{3}{*}{ Affective } & Pearson Correlation & $.572^{* *}$ \\
\hline & Sig. (2-tailed) & .006 \\
\hline & $\mathbf{N}$ & 130 \\
\hline \multirow{3}{*}{ Social } & Pearson Correlation & $.672^{* *}$ \\
\hline & Sig. (2-tailed) & .006 \\
\hline & $\mathbf{N}$ & 130 \\
\hline
\end{tabular}

As shown in table 4.5 there are significant correlations among the components of SILL and Tolerance of Ambiguity.

\subsection{Predicting EFL learners' LLSs through EI and tolerance of ambiguity}

A linear regression was run to predict EFL learners' LLSs by their EI and tolerance of ambiguity. As displayed in Fig. 1.1, the cluster of dots around the diagonal suggests linear relationships between the variables.

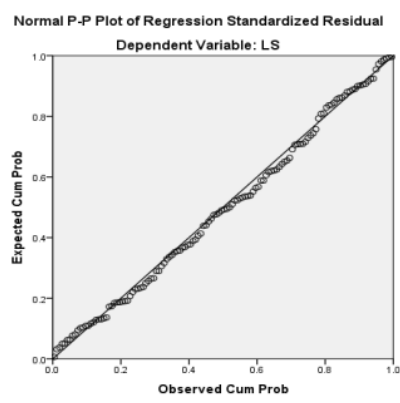

Figure 1.1: Normal P-P Plot: Linearity of Regression Model

The regression model converged in two steps (Table 4.). EI was the best predictor of LLSs ( $R=.26, \mathrm{R}^{2}=$ .068 ) and predicted 6.8 percent of students' LLSs.

Tolerance of ambiguity was the second best predictor of LLSs $\left(\mathrm{R}=.31, \mathrm{R}^{2}=.10\right)$. That is to say the regression model including EI and tolerance of ambiguity can predict about 10 percent of students' LLSs.

Table 4.6: Regression Output: Model Summary

\begin{tabular}{|l|l|l|l|l|}
\hline Model & $\mathrm{R}$ & R Square & Adjusted R Square & $\begin{array}{l}\text { Std. Error of the } \\
\text { Estimate }\end{array}$ \\
\hline 1 & $.261^{\mathrm{a}}$ & .068 & .061 & .520 \\
\hline 2 &. $\mathrm{316}^{\mathrm{b}}$ & .100 & .086 & .513 \\
\hline a. Predictors: (Constant), Emotional Intelligence \\
\hline \multicolumn{4}{|l|}{ b. Predictors: (Constant), EMI, Tolerance of Ambiguity } \\
\hline \multicolumn{4}{|l}{ c. Dependent Variable: Language Learning Strategies } \\
\hline
\end{tabular}

The results of the ANOVA test (Table 4.7) $\left(\mathrm{F}(2,127)=7.03, \mathrm{P}=.001, \omega^{2}=.08\right)$ indicated that the regression model enjoy statistical significance. 
Table 4.7: Regression Output: ANOVA

\begin{tabular}{|c|c|c|c|c|c|c|}
\hline \multicolumn{2}{|c|}{ Model } & Sum of Squares & df & Mean Square & $\mathbf{F}$ & Sig. \\
\hline \multirow{3}{*}{1} & Regression & 2.539 & 1 & 2.539 & 9.388 & $.003^{\mathrm{b}}$ \\
\hline & Residual & \begin{tabular}{|l|}
34.618 \\
\end{tabular} & 128 & .270 & & \\
\hline & Total & $\mathbf{3 7 . 1 5 7}$ & 129 & & & \\
\hline \multirow{3}{*}{2} & Regression & 3.707 & 2 & 1.853 & 7.037 & $.001^{\mathrm{c}}$ \\
\hline & Residual & \begin{tabular}{|l|}
33.450 \\
\end{tabular} & 127 & .263 & & \\
\hline & Total & 37.157 & 129 & & & \\
\hline \multicolumn{7}{|c|}{ a. Dependent Variable: Language Learning Strategies } \\
\hline \multicolumn{7}{|c|}{ b. Predictors: (Constant), Emotional Intelligence } \\
\hline \multicolumn{7}{|c|}{ c. Predictors: (Constant), EMI, Tolerance of Ambiguity } \\
\hline
\end{tabular}

Based on these results it can be concluded thatthe EI and tolerance of ambiguity can significantly predict students' LLSs and contributed significantly to the regression model.

\section{Discussion}

Extensive investigation has shown the importance of LLSs in making language learning more efficient and in producing a positive effect on learners' language use [56, 58,59,60]. The results of this study may provide a deeper understanding of strategy use among EFL learners. According to the results, a statistically significant relationship was found between EFL learners' EI and LLSs use. The present result is in consistent with the studies conducted by Rostami [61], Aghasafari[62], and Fouladi[63] who found a positive correlation between EI and LLSs.

Also, there has been a statistically significant relationship between EFL learners' tolerance of ambiguity and LLSs use. This finding is also in line with a number of other studies [64].Finally, it was concluded that EFL learners' EI and tolerance of ambiguity can significantly predict learners' LLS use. This finding is in line with Oxford and Ehrman's[41] work, which indicated that tolerance of ambiguity is a predictor of students' LLSs. Also, EI scales were found to have predictive power in using metacognitive strategies [65].

An awareness of the impact of ambiguity tolerance and EI, as a psychological construct on EFL learning, is of great importance and would result in teachers' modifications in planning and execution of lessons inorder to better help the students overcome psychological barriers. As Oxford\&Shearin [66] recommend, strategy use should be somewhat individualized in educational system. In other word, in order to provide successful instruction, teachers need to learn to identify and understand their students' individual differences. This may cause a shift from teacher to learner instruction, such as the learner-centered curriculum[67]. In such learners-based educational system, Cook[68] guides the teachers to make students aware of the range of the strategies they can adopt.In this way the gap in teacher-learner interaction can be minimized and the amount of attention to each and every learner can be increased.

\section{References}

[1]. M.Zarafshan.andM.Ardeshiri, The relationship between Emotional Intelligence, language learning strategies and English proficiency among Iranian EFL university students. Journal of educational and instructional studies in the world, 2(3), 2012,105-114.

[2]. L.F. Bachman. and A.S. Palmer,Language testing in practice(New York: Oxford University Press, 1996)

[3]. E.Bialystok.A,Theoretical model of second language learning.Language Learning, 28, 1978, 69-83.

[4]. M. Canale, andM. Swain, Theoretical bases of communicative approaches to second language teaching and testing.Applied Linguistics, 1,1980, 10-47.

[5]. R. Ellis. Understanding second language acquisition(Oxford: Oxford University Press, 1985).

[6]. P. Benson, and P.Voller,Autonomy and independence in language learning(London: Longman Group Ltd, 1997).

[7]. R.Oxford,Language learning strategies: What every teacher should know(New York: Newbury House Publishers, 1990)

[8]. S.Tabanlioğlu,The relationship between learning styles and language learning strategies of pre-Intermediate EAP students. Unpublished M.A. Thesis. Middle East Technical University, Ankara, Turkey, 2003.

[9]. A.Chamot, and L. Kupper, Learning strategies in foreign instruction. Foreign Language Annals, 22,1989, 13-24.

[10]. A. D. Cohen,Languagelearning: Insights for learners, teachers, and researchers(Boston: Heinle and Heinle Publishers, 1990).

[11]. M. Ehrman and R. L. Oxford, Adult language learning styles and strategies in an intensive training setting, The Modern Language Journal, 74(3),1990,311-327.

[12]. P. MacIntyreandR. Gardner, Anxiety and second language learning: Toward a theoretical clarification. Language Learning, 39, 1989,251-275.

[13]. J. Reid, The learning style preferences of ESL students. TESOL Quarterly, 21(1), 1989, 87-110.

[14]. A. Wenden, What do second-language learners know about their language learning? A second look at retrospective accounts,Applied Linguistics, 7, 1986,186-205.

[15]. R. Ellis, The study of second language acquisition (Oxford: Oxford University Press, 2008).

[16]. A.U.Chamot, S. Barnhardt, P.B. El-DinnaryandJ.Rubbins, The learning strategies handbook.(New York: Longman, 1999).

[17]. R. Ellis andB. Sinclair, Learning to learn English. (Cambridge: Cambridge University Press, 1989).

[18]. J. M.O'Malley, A. U.Chamot, G. Stewner-Manzanares, R. Russo and L. Kupper, Learning strategy applications with students of English as a second. TESOL Quarterly, 19 (3), 1985, 557-584.

[19]. S. Bremner, Language learning strategies and language proficiency: Investigating the relationship in Hong Kong. Canadian Modern Language Review, 55, 1999, 490-514.

[20]. J.M. Green and R. L. Oxford, A closer look at learning strategies, L2 proficiency, and gender. TESOL Quarterly, 29(2),1999, 261297.

[21]. R. Oxford andJ. Burry-Stock, Assessing the use of language learning strategies worldwide with the ESL/EFL version of the Strategy 
Inventory for Language Learning (SILL),System, 23(1), 1995, 1-23

[22]. M.Nosratinia, and E. Sarabchian, Predicting EFL learners' Emotional Intelligence and Critical Thinking ability through Big-Five Personality Traits: A study on psychological characteristics ofEFL learners. International Journal of Scientific \& Engineering Research, 4(9), 2013, 500-515.

[23]. R. L. Thorndike, Intelligence and its uses. Harpers Magazine, 140, 1920, 277-335.

[24]. R. L. Thorndike, The problem of classification of personnel. Psychometrika, 15,1950, 215-235.

[25]. P. Saloveyand J. D., Mayer, Emotional intelligence and the construction and regulation of feelings.Imagination, Cognition, and Personality, 9,1995, 185-211.

[26]. D. Goleman,Emotional Intelligence(New York: Bantam Books, 1995).

[27]. R. Bar-On, The Emotional Quotient Inventory (EQ-i): A test of emotional intelligence,(Toronto: Multi-Health Systems, 1997).

[28]. A. Carmeli, The relationship between emotional intelligence and work attitudes, behaviors and outcomes, Journal of managerial Psychology, 18, 2003, 788-813.

[29]. K. V. Petrides, N. Frederickson and A.Furnham, The role of trait Emotional Intelligence in academic performance and deviant behavior at school. Personality and Individual Differences, 36,2004, 277-293.

[30]. N. S. Shuttes, E. Schuetplez and J. M.Malouff, Emotional intelligence and task performance. Imagination, Cognition and Personality, 20, 2001, 347-354.

[31]. N. Ferres, and J. Connell, Emotional Intelligence in leaders: an antidote for cynicism towards change? Strategic Change, 13(2), 2004, 61-71.

[32]. D. Singh, Emotional intelligence at Work (2 ${ }^{\text {nd }}$ ed.)(New Delhi: Sage Publications, 2003).

[33]. N.M.Ashkanasy, Studies of cognition and emotion in organizations: Affective events, Emotional Intelligence and perception of emotion. Australian Journal of Management, 27,2002, 11-20.

[34]. K. Dearborn, Studies in Emotional Intelligence redefine our approach to leadership development. Public Personnel Management, 31(4), 2002, 523-530.

[35]. L. Gardner, and C.Stough, Examining the relationship between leadership and emotional intelligence in senior level managers.Leadership \& Organization Development Journal, 23(2),2002, 68-78.

[36]. E. Weymes, Relationships not leadership sustain successful organizations. Journal of Change Management, 3(4), 2002, $319-331$.

[37]. M. SlaskiandS.Cartwight, Health, performance and emotional intelligence: An exploratory study of retail managers. Stress and Health, 18,2002, 63-68.

[38]. P. Alaviniaand T.Ahmadzadeh,Toward a reappraisal of the bonds between Emotional Intelligence and burnout. English Language Teaching, 5(4),2012, 37-50.

[39]. P. Alavinia andS.Kurosh. The Bonds between EI and Self-Efficacy among Iranian EFL University Professors.In the Proceeding of 2012 First National Conference on Issues in English Literature and Language Teaching: New Trends and Criticisms atLorestan University, Lorestan, Iran, 2012.

[40]. B. Palmer, C. DonaldsonandC. Stough, Emotional Intelligence and life satisfaction. Personality and Individual Differences, 33, 2002, 1091-1100.

[41]. M. Ehrman, Ego boundaries revisited: Toward a model of personality and learning(Washington, DC: Georgetown University Press, 1993).

[42]. A. Z.Guiora, Language, personality, and culture, or the Whorfian hypothesis revisited. In M. Hines, W. Rutherford (Eds.), On TESOL 81 (pp. 169-177). (Detroit, MI: Teachers of English to Speakers of other Languages, 1981).

[43]. A. Furnham and T.Ribchester, Tolerance of Ambiguity: A review of the concept, its measurement and applications. Current Psychology, 14,1995,179-199.

[44]. C. M. Ely, Tolerance of ambiguity and use of second language learning strategies. Foreign Language Annals, 22(5), 1989, 437-445.

[45]. N. Naiman, M.Frohlich, H.Sternand A. Todesco,The good language learner(Toronto, Ontario: Institute for Studies in Education, 1978).

[46]. M. Ehrman andR. Oxford, Cognition plus: Correlates of language learning success. The Modern Language Journal, 79, 1995, 67-89.

[47]. L. M. Beebee, Risk-taking and the language learner. In H.W. Selingerand M. H., Long (Eds.), Classroom oriented research in second language acquisition (pp. 39-66),(Rowley, MA: Newbury House, 1983).

[48]. H. D. Brown,Principles of language learning and teaching (2 ${ }^{\text {nd }}$ ed.).(Englewood Cliffs, NJ: Prentice-Hall, 1987).

[49]. E. W. Stevick,Memory, Meaning and Method (Rowley: Newbury House Publishers, 1976).

[50]. R. Ellis, The study of second language acquisition (New York: Oxford University press, 1994).

[51]. A. F. AshouriandZ. Fotovatnia, The effect of individual differences on learners' translation belief in EFL learning,English Language Teaching, 3(4), 2010, 228-236.

[52]. I. H. Erten and E.Z.Topkaya, Understanding tolerance of ambiguity of EFL learners in reading classes at tertiary level. NovitasRoyal, 3(1), 2009, 29-44.

[53]. C. A. Chapelle, The relationship between ambiguity tolerance and success in acquiring English as a second language in adult learn ers (Unpublished doctoral dissertation). University of Illinois, Illinois, USA, 1983.

[54]. C. A.Chapelle, C. Robert, Ambiguity tolerance and field independence as predictors of proficiency in English as a Second Language, Language Learning, 36, 1986, 27-45.

[55]. M. A. Reiss, The good language learner: Another look, Canadian Modern Language Review, 41,1985, 511-523.

[56]. R. Oxford,Learning strategies around the world: Cross-cultural perspectives(Honolulu: University of Hawaii Press, 1996).

[57]. C. M. Ely, Tolerance of ambiguity and the teaching of ESL. In J. M. Reid (Ed.), Learning styles in the ESL/EFL classroom (pp.102118),(Boston: Heinle and Heinle, 1995).

[58]. A. D. Cohen and J. S. Weaver, Strategies-based instructions for second language learners. In W.A. Renandya and G. M. Jacobs (Eds.), Learners and language learning (pp. 1-25),(Singapore: SEAMEO Regional Language Centre, 1998).

[59]. J. M.O'Malley, andA. U. Chamot, Learning strategies in second language acquisition,(Cambridge: Cambridge University Press, 1990).

[60]. A. WendenandJ. Rubin, Learner strategies in language learning(Hertfordshire: Prentice Hall, 1987).

[61]. S. Rostami, The relationship between emotional intelligence and Iranian EFL learners' language learning strategy use, Unpublished M.A. thesis. Islamic Azad University of Central at Tehran Branch, Tehran, Iran, 2010.

[62]. M.Aghasafari,On the relationship between emotional intelligence and language learning strategies, Unpublished M.A. thesis,AllamehTabataba'i University, Tehran, Iran, 2006.

[63]. M. Fouladi,The effects of Emotional Intelligence on the choice of language learning strategies, Indian Journal of Education and Information Management, 5(11), 2012, 518-526.

[64]. S. Karbalaee Kamran, Effect of gender on ambiguity tolerance of Iranian English language learners, Journal of Education and 
Practice, 2(11), 2011,25-34

[65]. P. AlaviniaandH.Mollahossein, The predictive power of Emotional Intelligence subscales for Iranian academic EFL Learners' use of listening Metacognitive Strategies: What part does gender have to play? International Research Journal of Applied and Basic Sciences,3(11), 2012,2231-2238.

[66]. R. Oxford and J.Shearin, Language Learning Motivation: Expanding the Theoretical Framework. The Modern Language Journal, 78 (1), 1994,12-28.

[67]. I. Tudor,Learner-centeredness as language education (Cambridge: Cambridge University Press, 1996).

[68]. V. Cook, Second language learning and language teaching(London: Edward Arnold, 2008). 